\title{
膜型圧電セラミックスを用いた縮小梁架構の鉛直微振動制御に関する研究 新機能性材料を用いた自己適応制御建築に関する研究（その 1 ) \\ A STUDY ON VERTICAL MICRO-VIBRATION CONTROL OF A REDUCED BEAM MODEL USING A FILM TYPE PIEZO-ELECTRIC DEVICE
}

A study on self-adaptive control of the building construction using new functional materials

松下仁士*, 吉岡宏和**, 高橋良 典**

\section{Hitoshi MATSUSHITA, Hirokazu YOSHIOKA and Yoshinori TAKAHASHI}

\begin{abstract}
This paper discusses on a control method of vertical micro-vibration of a beam using film type piezo-electric devices at the lower flange of the beam end. First, the actuator and the sensor characteristics of the film type piezo-electric device are shown. Secondly, the simulation method of estimating actuating force due to the device is shown using finite element analysis. Excitation test of the beam model using the device shows the validity of this simulation method. Finally, the experiment of controlling vertical micro-vibration of the beam using the film type piezo-electric devices as the actuator and the sensor is conducted, and effectiveness of the control system is proven.
\end{abstract}

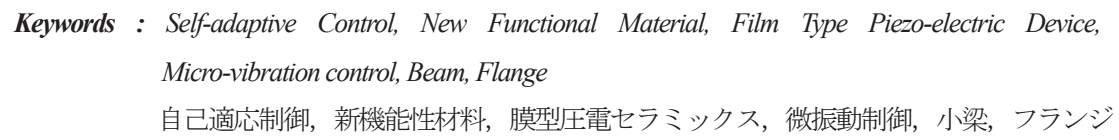

\section{1. はじめに}

建物周辺の交通や建物内における歩行, 設備の稼働などに起因す る振動が工場等における加工精度や住居等における居住性の観点か ら問題となる場合がある.こうした建物に生じる微細な振動 (以降, “微振動”と記す) への対策として,アクティブ・マス・ダンパ(AMD) 等に代表される ‘アクティブ制御システム’ の適用が広まりつつあ る 1),2). しかしながら，これらの制御システムは加速度計等のセン サ，油圧式あるいは電磁式等のアクチュエータ，アクチュエータを 駆動させるコントローラからなる制御システムと, 付加質量等で構 成され梁や床上に設置されるため, システムの複雑化や大型化, 設 置スペースの確保等の観点から採用が困難となる場合がある.

一方近年，薄膜状や繊維状といったような小型で柔軟性を有し， さらにはセンサとしてもアクチュエータとしても用いることができ る新しい機能性材料（以降，“新機能性材料” と記す）の開発が進ん でいる. これらの新機能性材料は, 様々な形状の構造体に直接貼付 あるいは埋め込むことができるため, 従来のアクティブ制御システ ムと比較して, 構造体との一体化を飛躍的に向上させることが可能 であり，構造体がいわば筋肉や神経としての機能を持ち自ら振動制 御を行う ‘自己適応制御システム’ の実現を可能にする材料として 期待されている。図 1 に従来のアクティブ制御システムと自己適応 制御システムの概念図を比較して示寸.

新機能性材料を用いた自己適応制御システムに関する研究は，特
に航空・宇宙工学，機械工学の分野において盛んに行われており， 主に柔軟, 軽量構造体の振動制御に関連して多く研究がなされてい る ${ }^{3), 4)}$. 特に欧州ではこのような新機能性材料と構造体とを一体化 させることにより実現する制御概念は“アダプトロニクス’と呼ば れ，近年盛んに研究がなされている5).

建築構造物の柱や梁にアクチュエータを直接設置して振動を制御 する試みは, ‘スマート構造’として一時期精力的に研究されている. 嶋崎ら ${ }^{6)}$,7), Hora ら 8) は, 固体のピエゾアクチュエータを構造物の 梁や柱に設置して，微振動をアクティブに制御することを試みてい る.これらの研究では, 架構の水平振動と鉛直振動を制御するため には，それぞれ個別のデバイスが必要であった。

新機能性材料を用いた自己適応制御に関する研究は，建築分野に おいてもいくつかなされている，竹下ら 9)や安達ら 10) は，片持ち平

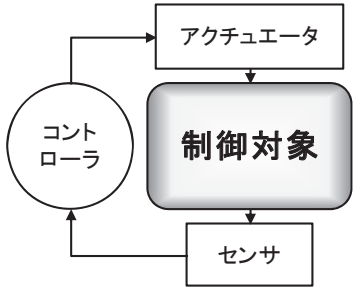

(a)アクティブ制御システム

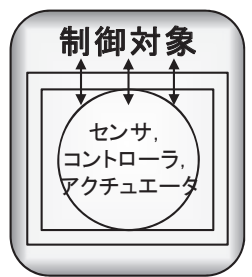

(b)自己適応制御システム
図 1 アクティブ制御システムと自己適応制御システムの概念図 
板に薄板状の圧電セラミックスを貼付し, その圧電効果により機械 的な振動エネルギを電気エネルギに変換し，これを熱エネルギとし て消費することで付加減衰を与える ‘圧電ダンパ’についてその有 効性を示している. 加えて, 圧電セラミックスをアクチュエータと して用い，別途平板の先端に取付けた加速度センサの信号をもとに したアクティブ振動制御について解析, 実験の両面から検討を行っ ている ${ }^{11}$. 熊谷ら ${ }^{12)}$ は, アーチ構造物を模擬した薄板模型に薄膜状 の圧電セラミックスを貼付し，模型外部に設置したレーザ変位計か ら得られる薄板の変位信号を基にアクティブ振動制御を行う実験を 実施している。これらはいずれも制御対象である構造体に新機能性 材料を直接貼付することで構造体と新機能性材料とを一体化し，ア クティブ振動制御を実現している。しかしながら, これらの研究で は, 片持ち平板などの軽量で摇れやすい構造体に対する振動制御し か実現できていない.

本研究は, 微振動を対象として, 新機能性材料と建築構造体とを 一体化させ，構造体自身にセンサとアクチュエータの機能を持たせ た ‘自己適応制御”を重量構造物である建築構造で実現することを 最終目標としている. 本研究で目指している建築構造の制御手法 ${ }^{13)}$ の概要を図 2 に示す．柱梁などの接合部に与えるモーメントの向き を制御することにより, 同じデバイスで鉛直振動と水平振動が制御 可能となるという特徵を有している.

本報では, 新機能性材料の一例として, 膜型圧電セラミックス ${ }^{14)}$ を取り上げ，センサ特性およびアクチュエータ特性を明らかにし， これを建築構造体に組込んだ制振架構について解析と実験の両面か ら検討を行った。 なお本報告では, アクチュエータ機能とセンサ機 能は, 別々の膜型圧電セラミックスで行うものとする. また, 制御 対象は，居室における居住性能や精密加工を行う製造施設における 生産性, 加工精度等の観点から問題となりやすい数〜数十 $\mathrm{Hz}$, 数〜 数十 $\mathrm{gal}$ 程度の鉛直微振動を対象とし, 主にこのような振動に寄与 する小梁の振動制御について検討した.

\section{2. 膜型圧電セラミックスを用いた梁の鉛直振動制御手法}

図 3 および表 1 に, 本検討で用いた膜型圧電セラミックスの概要 を示す. 膜型圧電セラミックスは, 直径数 $100 \mu \mathrm{m}$ の繊維状に成形 されたピエゾ素子を面的に並べた層，これらを結合するためのエポ キシ接着剤の層, 正極と負極をピエゾ素子に対して垂直方向に交互 に並べた電極をポリイミド樹脂にプリントした層で構成されている. 電極に電圧を印加することで図に示寸矢印方向に伸縮する.一方で, 外力を加え矢印方向に伸縮させることで電極間に電圧を発生する.

膜型圧電セラミックスを用いた梁の振動制御手法として, 図 4 に 示寸方法を考案した。梁両端部の下フランジ部分に膜型圧電セラミ

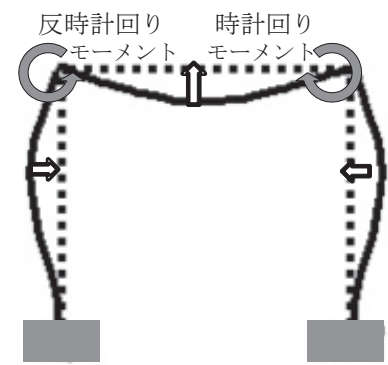

(a) 上下振動

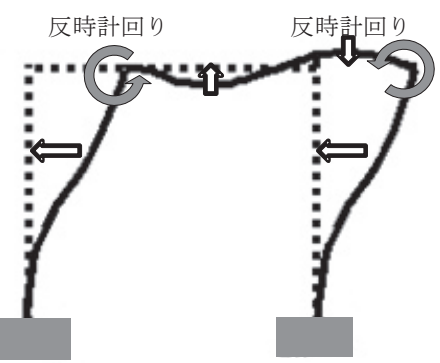

(b) 水平振動
図 2 柱梁接合部へのモーメント付与による建築架構の振動制御手法
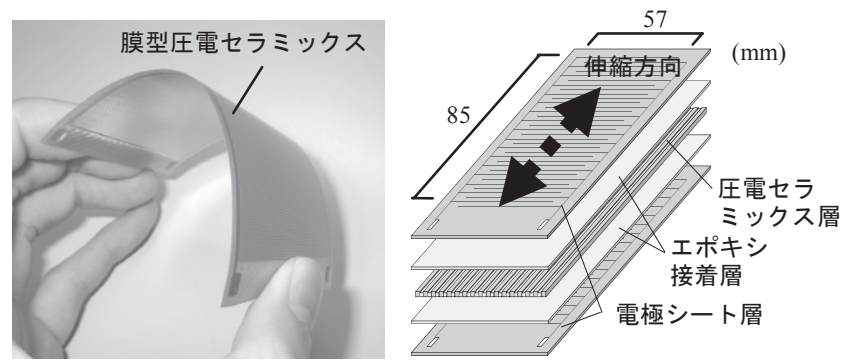

図 3 膜型圧電セラミックスの概要 ${ }^{14)}$

表 1 膜型圧電セラミックスの緒元

\begin{tabular}{|l|c|}
\hline 全体サイズ & $103 \times 64(\mathrm{~mm})$ \\
\hline 駆動部範囲 & $85 \times 57(\mathrm{~mm})$ \\
\hline $\begin{array}{c}\text { 弾性係数 } \\
\text { (長さ,幅方向 })\end{array}$ & $3.03 \times 10^{4}\left(\mathrm{~N} / \mathrm{mm}^{2}\right)$ \\
\hline $\begin{array}{c}\text { 弾性係数 } \\
\text { (厚さ方向 })\end{array}$ & $1.59 \times 10^{4}\left(\mathrm{~N} / \mathrm{mm}^{2}\right)$ \\
\hline 圧電定数 & $1.20(\mathrm{ppm} / \mathrm{V})$ \\
\hline 静電容量 & $9.30(\mathrm{nF})$ \\
\hline 許容印加電圧 & $-500 \sim+1,500(\mathrm{~V})$ \\
\hline
\end{tabular}

ックスを貼付した鋼板を配置する．梁の鉛直振動は，梁端部の下フ ランジ部分において水平挙動となるため, ここで圧縮, 伸長される 膜型圧電セラミックスから発生する電圧信号を検出することにより 梁の鉛直振動のセンシングを行うことができる，一方で，膜型圧電 セラミックスに電圧を印加し能動的に圧縮, 伸長させることにより, 柱梁接合部を支点とした曲げモーメントを発生させ，梁の鉛直振動 を制御することができる，この手法により建築構造にセンサ，アク チュエータが組込まれた形となり，センシング機能とアクチュエー ション機能を併せ持った構造物となる.

本研究では, 最終的には一つの膜型圧電セラミックスをセンサ兼 アクチュエータとして用いて振動制御を行うことを目的としている が，本報では基礎的段階として両端部の膜型圧電セラミックスのう ち一方をセンサ, 他方をアクチュエータとして機能を切り分けて制 御系を構築することを検討した。

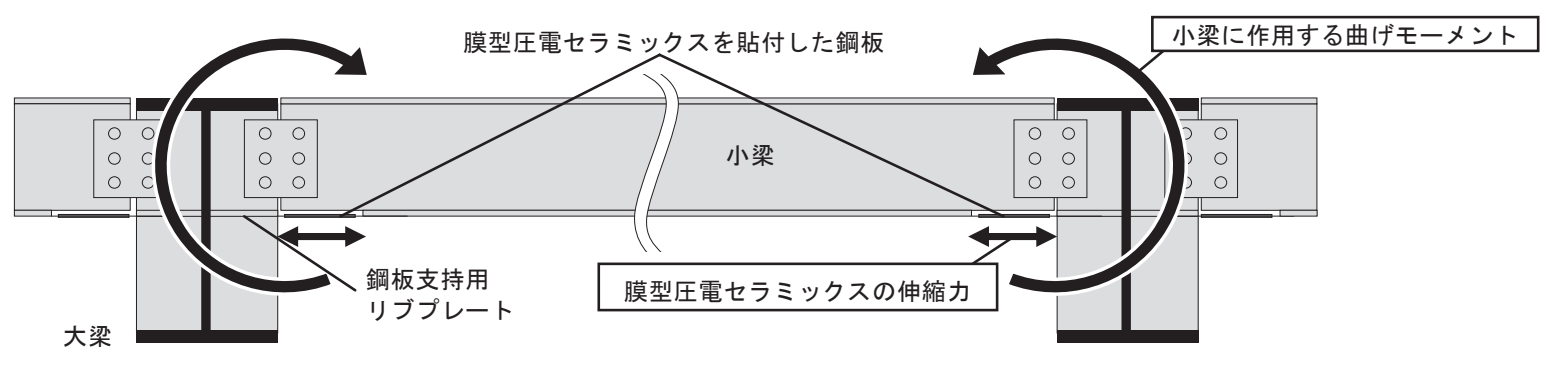

図 4 膜型圧電セラミックスを用いた梁の鉛直微振動制御手法 


\section{3. 膜型圧電セラミックスの基本特性}

\section{1 膜型圧電セラミックスのアクチュエータ特性}

本報で用いた膜型圧電セラミックスのアクチュエータ特性として, 発生力と振幅の振動数依存性および応答速度を確認する実験を行っ た。図 5 に実験装置の概要を示す。実験装置は, 膜型圧電セラミッ クスを両面に貼付した鋼板とこれを固定する治具およびリニアガイ ドから構成される．膜型圧電セラミックスと鋼板との間にはあらか じめ歪ゲージを貼付し，リニアガイド側の固定部には加速度センサ を設置している，膜型圧電セラミックスを駆動する際には発振器か ら出力される電圧信号を専用アンプにて 200 倍に増幅し, 膜型圧電 セラミックスへ印加する。使用したリニアガイドの動摩擦係数は 0.004 0.006 と極めて小さく, 摩擦が実験に及ぼす影響は無視でき るものと考えた.

膜型圧電セラミックスに電圧を印加した際の鋼板の歪量と断面積 およびヤング係数 $\left(2.05 \times 10^{5} \mathrm{~N} / \mathrm{mm}^{2}\right)$ から発生力を算出した。 なお歪 量は, 鋼板の両面に貼付した歪ゲージより得られた值の平均値とし た. 図 6 に, 膜型圧電セラミックスへの印加電圧と算出された膜型 圧電セラミックス一枚当りの発生力との関係を示す，発生力は，印 加電圧と概数線形の関係にあり, 最大圧縮力から最大引張力までの 差は約 $926 \mathrm{~N}$ であった。

続いて発振器から出力される電圧信号から加速度センサにて得ら れる応答加速度までの伝達関数を計測し, 振幅倍率より振幅の振動 数依存性を, 位相差より応答速度を確認した。電圧信号は振幅が一 定で振動数が 1〜 $100 \mathrm{~Hz}$ のスイープ信号とした. 図 7 に, 得られた 伝達関数の振幅倍率および位相差を示寸. 図中の破線は, 得られた 伝達関数を 2 階積分し, 電圧信号から応答変位までの伝達関数に換 算したものである。図より, 膜型圧電セラミックスの応答は電圧信 号に対して変位振幅がほぼ一定となり, 少なくとも $100 \mathrm{~Hz}$ までは平 坦な特性であることがわかる。 また，振動数が大きくなるに従って 位相が遅れ，100Hz において電圧信号に対する応答変位の位相遅れ は約 $45^{\circ}$ となった.この結果より, 用いた膜型圧電セラミックスと 専用アンプによるアクチュエータの応答速度は $1 / 100 \times 45 / 360=$ $0.00125 \mathrm{~s}$ であり, 本検討で対象とする数十 $\mathrm{Hz}$ 程度までの梁の振動 制御に十分適用可能であることが確認された.

\section{2 膜型圧電セラミックスのセンサ特性}

図 5 に示寸装置を用いて膜型圧電セラミックスのセンサ特性を確 認する実験を行った。鋼板の両面に貼付した膜型圧電セラミックス のうち一方に電圧を印加して駆動し，他方の膜型圧電セラミックス より得られる電圧信号を計測した。 同時にリニアガイド側固定部に 取り付けた加速度センサより得られる加速度信号も計測した.

図 4 に示寸伸縮方向のみの変形を考えた場合, 膜型圧電セラミッ クスの機械的, 電気的特性は以下に示寸圧電方程式で表される.

$$
\begin{aligned}
& D=\varepsilon^{T} E+d_{31} T \\
& \varepsilon=d_{31} E+s^{E} T
\end{aligned}
$$

$\mathrm{D}$ : 電束密度 $\left(\mathrm{C} / \mathrm{m}^{2}\right), \mathrm{E}$ : 電場 $(\mathrm{V} / \mathrm{m}), \mathrm{T}$ : 応力 $\left(\mathrm{N} / \mathrm{m}^{2}\right), \varepsilon$ : 歪, $\varepsilon^{\mathrm{T}}$ : 誘電率 $(\mathrm{C} / \mathrm{Vm})$ (ただし $\mathrm{T}=$ const.), $\mathrm{d}_{31}$ : 圧電歪定数 $(\mathrm{C} / \mathrm{N})$, $\mathrm{s}^{\mathrm{E}}$ : 弾性コンプライアンス $\left(\mathrm{m}^{2} / \mathrm{N}\right)$ (ただし $\mathrm{E}=$ const. $)$ ここで，(1)式の第一式の両辺に膜型圧電セラミックスの断面積 $\mathrm{A}\left(\mathrm{m}^{2}\right)$ を乗じることにより, 膜型圧電セラミックスに外力 $\mathrm{F}(\mathrm{N})$ を与

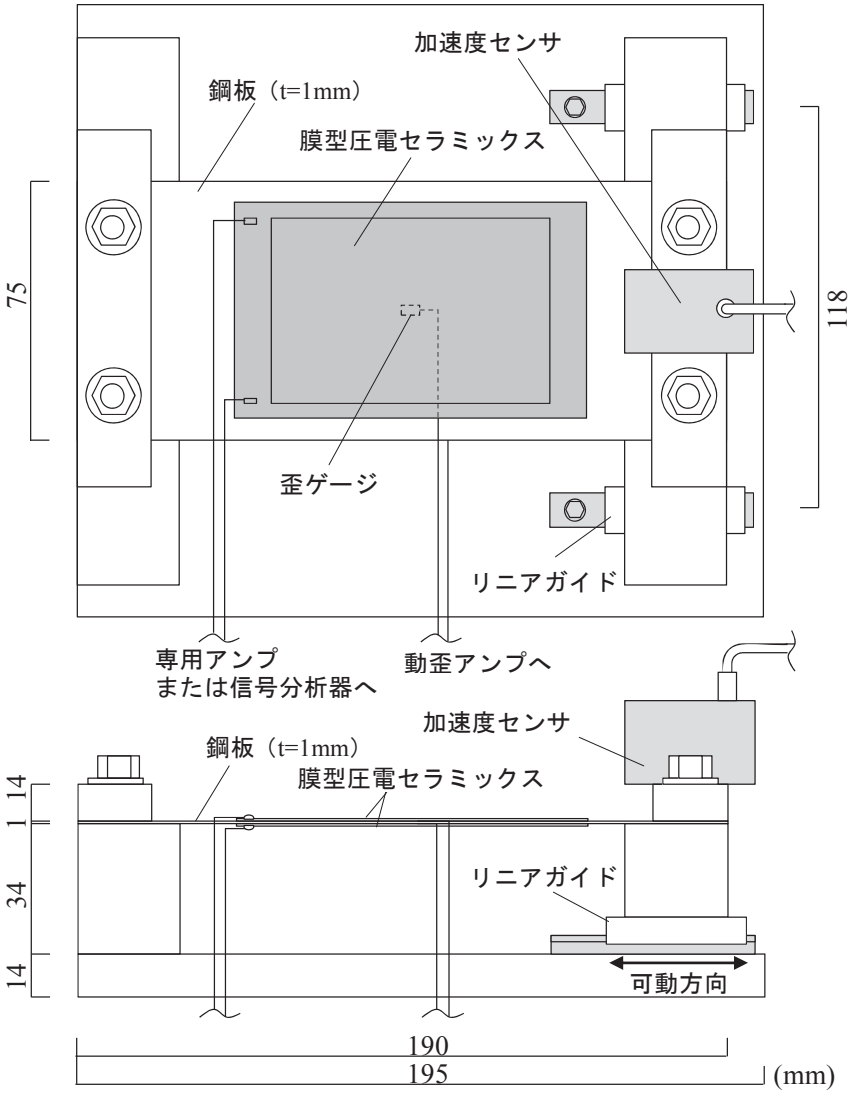

図 5 膜型圧電セラミックスの基本特性実験装置

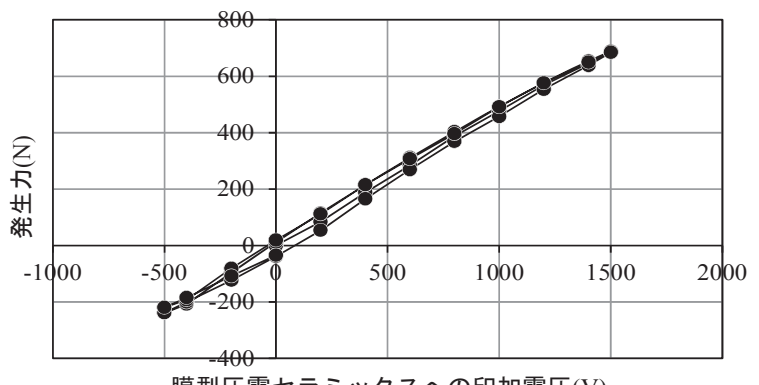

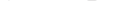
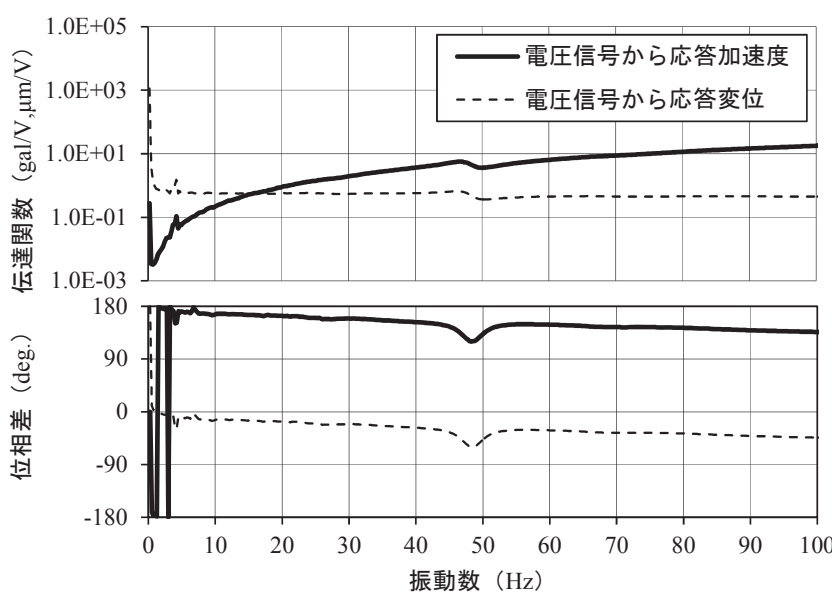

図 7 膜型圧電セラミックスのアクチュエータ特性 (振動数依存性と応答速度) 
えた際に発生する全電荷量 $\mathrm{Q}(\mathrm{C})$ が得られる.ただし膜型圧電セラミ ックスには外部から電圧を印加しないものとして電場 $\mathrm{E}=0$ とおく.

$$
\begin{aligned}
& D \cdot A=\left(\varepsilon^{T} E+d_{31} T\right) \cdot A \\
& Q=d_{31} F
\end{aligned}
$$

また, 膜型圧電セラミックスに接続する計測器に流れる電流を I(A), インピーダンスを $\mathrm{Z}(\Omega)$, 計測器にて計測される電圧を $\mathrm{V}(\mathrm{V})$ とする と, 電荷 $\mathrm{Q}$ は以下のように表わされる.

$$
Q=\int_{0}^{\infty} I d t=\int_{0}^{\infty} \frac{V}{Z} d t
$$

(2)式と(3)式より，下式が得られる.

$$
V=d_{31} Z \frac{d F}{d t}
$$

(4)式より, 計測される電圧信号は膜型圧電セラミックスに加えられ る外力の時間微分すなわち膜型圧電セラミックスの変形速度に比例 することがわかる.

図 8 に, リニアガイド側固定部の加速度計にて得られる加速度信 号に対するセンサ用膜型圧電セラミックスから得られる出力電圧信 号の振幅倍率および位相差の関係を示寸. 図中の破線は, 加速度信 号を 1 階積分し速度としたものに対するセンサ用膜型圧電セラミッ クスの出力電圧信号の関係を示している. 図より，上述のとおり， 膜型圧電セラミックスをセンサとして用いた場合の電圧信号は膜型 圧電セラミックスの変形速度に依存していることがわかる。また, 少なくとも $100 \mathrm{~Hz}$ まではほとんど位相遅れなく応答することが確 認された。

\section{4. 膜型圧電セラミックスによる縮小梁模型の加力実験}

実際に梁架構に膜型圧電セラミックスが組込まれた際に発揮でき る加振力を把握することを目的として, 縮小梁模型を製作し膜型圧 電セラミックスによる加力実験および解析による加振力推定手法の 検討を行った。

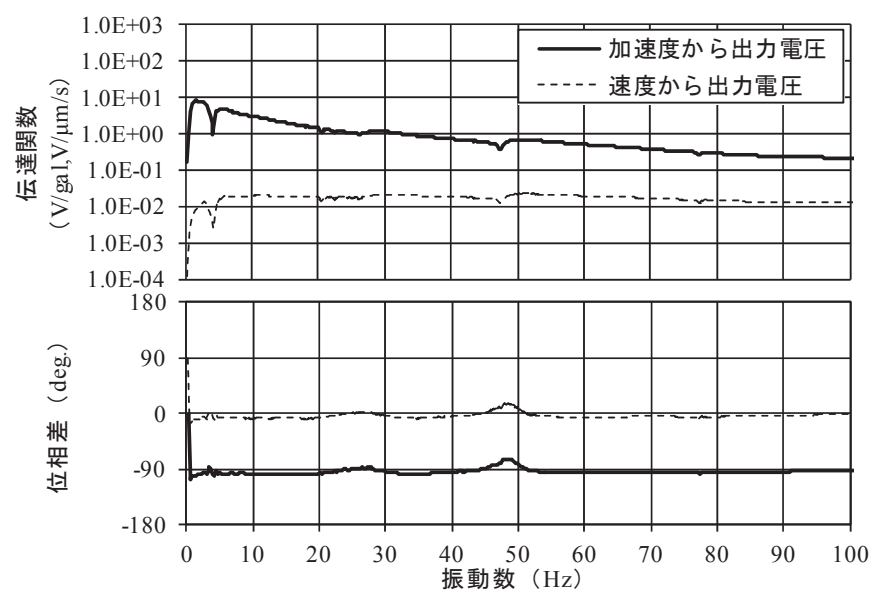

図 8 膜型圧電セラミックスのセンサ特性

\section{1 縮小梁模型の概要}

図 9 に縮小梁模型の概要を示す。梁部材は, 長さが $3,000 \mathrm{~mm}$ の $\mathrm{H}-100 \times 50 \times 5 \times 7$ であり，梁両端部は鉄骨柱（ $\square-250 \times 250 \times 4 ） に$ 取り付 けたガセットプレートとウェブ部分を, 高力ボルト（F8T, M12×4） と添接鋼板 $(90 \times 74 \mathrm{~mm}, \mathrm{t}=3.2)$ を用いた 2 面摩擦接合にて固定して いる. 梁上には, スラブの重量を模擬するため約 $200 \mathrm{~kg} / \mathrm{m}$ の重錘を 載荷した。梁の中央部には外乱振動を発生させるための起振機を設 置している．試験体の規模は実際の建築構造におけるスパンの $1 / 2$ 〜 1/3 程度を想定し, これに合わせて梁の断面やスラブ重量を模擬 した重錘の大きさを設定している.

梁両端部の下フランジ部分を約 $120 \mathrm{~mm}$ に渡り切り欠き, 膜型圧 電セラミックスを両面に貼付した厚さ $1 \mathrm{~mm}$ の鋼板をボルト接合に て配置した (図 9(b)(c)参照)。ここで，鋼板と下フランジ部分との ボルト接合を行う際には, 予め膜型圧電セラミックスに+1,500V を 印加し鋼板に伸長方向の予歪を与え, 鋼板と膜型圧電セラミックス が常に収縮方向すなわち梁の下フランジを引張る方向に力を伝達す るよう配慮した。これは, 膜型圧電セラミックスへの印加電圧が 0 〜 $1,500 \mathrm{~V}$ の間では, 膜型圧電セラミックスおよび鋼板が伸長するた

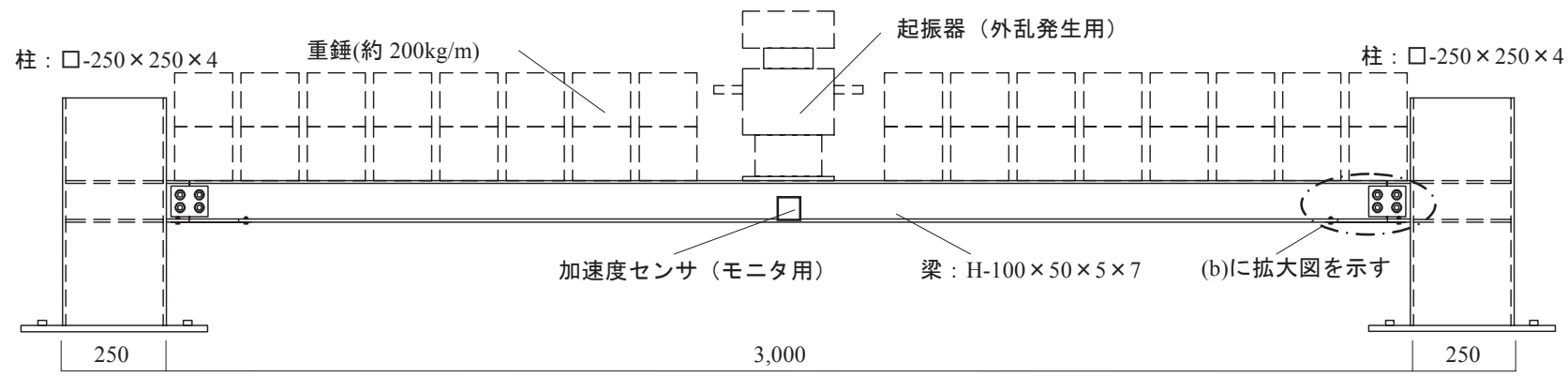

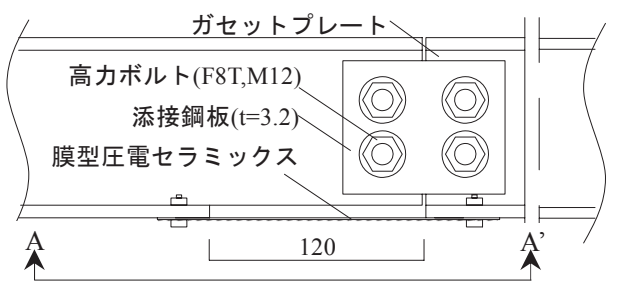

(b)梁端部拡大図

(a)全体図

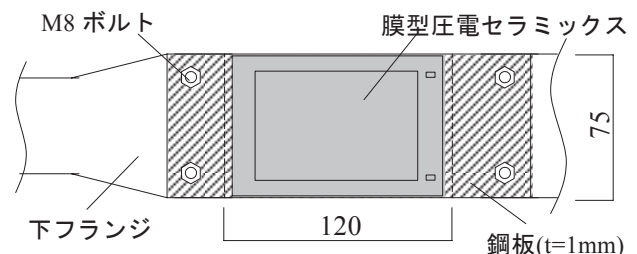

(c)下フランジと膜型圧電セラミックスの取合い（A-A'矢視）

図 9 縮小梁模型の概要 
め, 梁の下フランジと固定されている鋼板に面内方向の圧縮力が発 生し, 面外座屈により梁に有効に制御力を伝達できないことが懸念 されたためである.

なお，制御力が不足した場合を想定して，鋼板の両面に膜型圧電 セラミックスを 1 層ずつ貼付したものの他に, 2 層ずつ貼付したも の, 3 層ずつ貼付したものも用意し, 膜型圧電セラミックスの複層 化による制御力の増強の検討も行うこととした．以上の縮小梁模型 の一次固有振動数および減衰定数を測定した. 梁両端部の膜型圧電 セラミックスに振幅が一定で振動数が 1 〜 $100 \mathrm{~Hz}$ のスイープ電圧を 印加し振動させた際の梁中央部における共振曲線より算定した結果, 一次固有振動数は $10.6 \mathrm{~Hz}$ であった。 また, 膜型圧電セラミックスの 専用アンプへの入力電圧信号から梁中央部の加速度センサ信号まで の伝達関数より $1 / \sqrt{2} 2$ 法を用いて減衰定数を算定した結果，約 $1.1 \%$ であった。

\section{2 有限要素法解析を用いた縮小梁模型の挙動推定手法}

膜型圧電セラミックスを駆動させた際に生じる梁の鉛直振動を解 析的に推定した. 解析手法には, 膜型圧電セラミックスや梁架構の 境界条件などを詳細かつ比較的自由に設定できるよう有限要素法 (以降「FEM」と記す) を用いることとし, 汎用 FEM 解析ツールで ある ‘建設用構造解析システム midas Gen’を用いた。 なお，本検 討では解析対象を膜型圧電セラミックスおよび梁の静的挙動, 一次 固有振動数とした. また, 梁の固有振動数において膜型圧電セラミ ックスを駆動させ共振させた場合の梁中央部における最大加速度 $a_{\max }$ は, 梁の減衰定数 $\xi か ゙$ 小さい場合には固有角振動数 $\omega$ を用い て以下のように求められる.

$$
a_{\max }=\frac{\delta \omega^{2}}{2 \xi}
$$

こうして求められる梁中央部の最大加速度が膜型圧電セラミックス を駆動させることにより発揮できる加振力に相当するものと考えた. また, 本検討では膜型圧電セラミックスの圧電効果を熱膨張効果 と置き換えて設定し, 圧電特性を再現することとした. すなわち, 前述の(1)式に示寸圧電方程式の第二式において, 圧電定数 $\mathrm{d}_{31}$ を熱 膨張係数 (歪/部材温度) と読夕替えて膜型圧電セラミックスの伸縮 方向にのみ設定し, 入力電圧として部材温度負荷を与えた.例えば, $1500 \mathrm{~V}(\mathrm{DC})$ を印加する場合は, 膜型圧電セラミックスに $1500^{\circ} \mathrm{C}$ の部 材温度負荷を疑似的に加えることにより，等価なひずみを与えた。

膜型圧電セラミックスおよび梁架構のモデル化にはソリッド要素 を用いた. 梁の材軸方向を $100 \mathrm{~mm}$ 間隔で分割し, ウェブは 6 分割, フランジは 3 分割とした。梁材等の鋼材の剛性は $2.05 \times 10^{5} \mathrm{~N} / \mathrm{mm}^{2}$ とし, 膜型圧電セラミックスの剛性には表 1 に示した数值を用いた. 梁端部のボルト接合部分では添接鋼板もモデル化し, 高力ボルト配 置部分については梁のウェブ材を含めて剛体とした.

以上により作成した解析モデルの一次固有振動数（鉛直）は $10.7 \mathrm{~Hz}$ であり実測結果とほぼ一致した. 以降で梁模型の挙動推定結 果と実験結果を示し，これらを比較することにより本推定手法の有 効性を検討する.

\section{3 静的加力実験}

図 10 に, 膜型圧電セラミックスに DC 電圧を印加し梁に静的加力 を行った際の梁中央部における鉛直変位の解析值および実験值を示

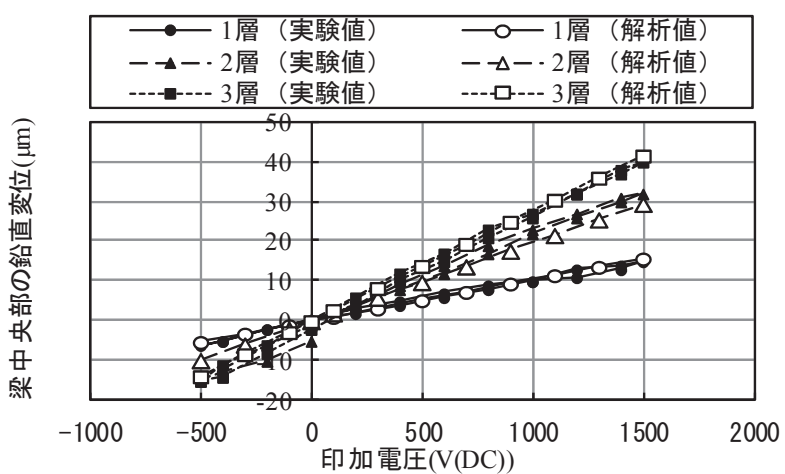

図 10 膜型圧電セラミックス駆動時の 梁中央部における静的鉛直変位

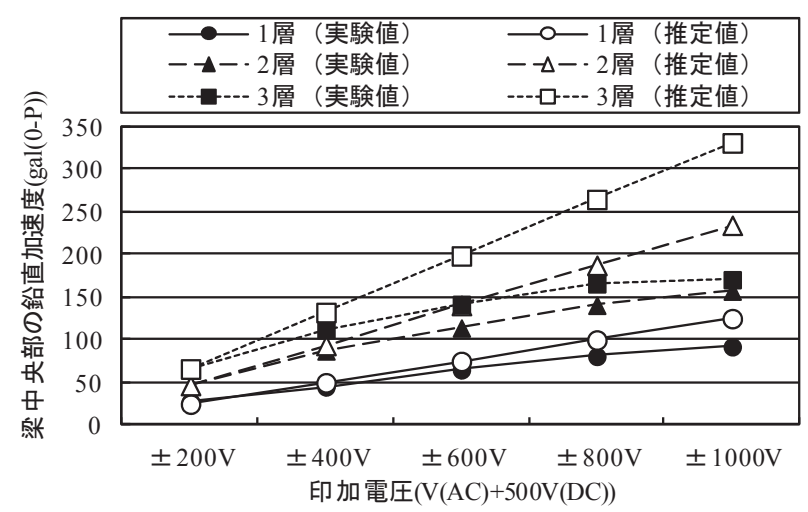

図 11 膜型圧電セラミックス駆動時の梁中央部における最大加速度

す. 解析值と実験值は概ね一致しておりモデル化手法の妥当性が確 認された。 また, 膜型圧電セラミックスを 1 層とした場合と比較し て, 2 層, 3 層とした場合, 最大鉛直変位が増加する傾向が見られる. 許容最大電圧である $+1,500 \mathrm{~V}$ 印加時の静的変位の実験值を見ると, 膜型圧電セラミックスを 2 層とした場合は, 1 層の場合と比較して 約 2.11 倍, 3 層の場合は約 2.67 倍となっており，積層枚数を増や すに従い増幅効率は減少するものの, 膜型圧電セラミックスの積層 によりある程度の制御力の増強が期待できることが確認できた.

\section{4 動的加力実験}

続いて, 膜型圧電セラミックスに $\mathrm{AC}$ 電圧を印加し梁模型を加振 する実験を行った，印加電圧は+500V を中心とした正弦波で，片振 幅を $200 \mathrm{~V} \sim 1,000 \mathrm{~V}$ の間で 5 段階設定した。実験中，加速度振幅に よって共振振動数が変化する様子が伺えたため, 印加する $\mathrm{AC}$ 電圧 の振動数を梁模型の一次固有振動数近傍において $0.05 \mathrm{~Hz}$ 刻みで変 化させ, 梁中央部における加速度振幅が最も大きくなった時の值を 記録した. 図 11 に, FEM 解析により算定された静的変位と(5)式お よび共振振動数から得られる梁中央部の加速度振幅の推定值と, 実 際に膜型圧電セラミックスを駆動させることにより得られた実測值 を併せて示す. 解析結果からは, 印加電圧に対して線形に増加し, 積層枚数 3 層の場合, 最大で約 $300 \mathrm{gal}(0-\mathrm{P})$ となることが推定された が，実験では，印加電圧の振幅が大きくなるにしたがって加速度振 幅も増えていくものの, その増幅度合いは徐々に小さくなっていく 傾向が見られた．この傾向は，膜型圧電セラミックスの積層枚数に よらず，いずれの場合も加速度振幅がおよそ $50 \mathrm{gal}(0-\mathrm{P})$ より大きく なる場合に見られる。 この要因として, 減衰定数が梁中央部の加速 度振幅に依存している事が考えられる.

減衰定数の振幅依存性を確認することを目的として, 膜型圧電セ 
ラミックスに+500V を中心とした正弦波で振幅の異なる数段階の スイープ電圧を印加し, それぞれ専用アンプヘの入力信号から梁中 央部の加速度センサ信号までの伝達関数より $1 / \sqrt{2} 2$ 法を用いて減衰 定数を算定した. 図 12 に, 膜型圧電セラミックスによる加振時の 伝達関数を示す．凡例はアンプへの入力電圧を表している．また， 図 13 に梁中央部に設置した加振器による加振時の加振力に対寸る 梁中央部の加速度応答への伝達関数を示す. 凡例は梁中央部の最大 応答加速度 $(0-\mathrm{P})$ を表している. 膜型圧電セラミックスへの印加電 圧の振幅を大きくするに従って固有振動数が低くなり，伝達関数の ピーク值が小さくなっているが, 同様の現象は加振器による加振時 にも認められる. 従って, これらの非線形性状は, 膜型圧電セラミ ックスに起因するものではなく, 梁端部のボルト接合部の微小な緩 みなどの要因によるものであると考えられる。

図 14 に, スイープ加振した際の共振時の最大加速度振幅と, 図 12 の伝達関数より $1 / \sqrt{2} 2$ 法を用いて算定される減衰定数との関係を 示寸. また, 戝には加速度振幅と減衰定数の関係を直線近似した場 合の回帰直線と回帰式および決定係数 $\mathrm{R}^{2}$ を併せて示した. この回帰 式と伝達関数のピークを示寸振動数を前述の(5)式に適用し最大加 速度 $a_{\text {max }}$ を推定した結果を図 15 に示寸. 推定值と実測值は比較的 よく一致しており, 前述の FEM 解析手法と減衰定数の適切な設定に より, 膜型圧電セラミックスによる梁の加振力を推定できることが 確認された。

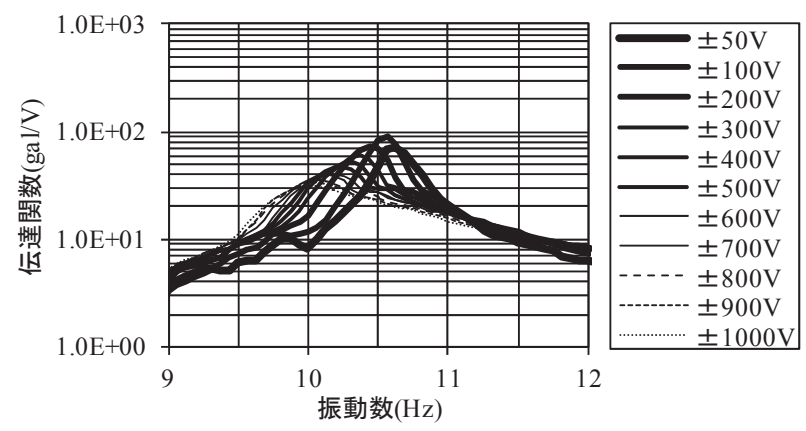

図 12 膜型圧電セラミックス加振時における専用アンプへの 入力信号から梁中央部の加速度センサ信号までの伝達関数

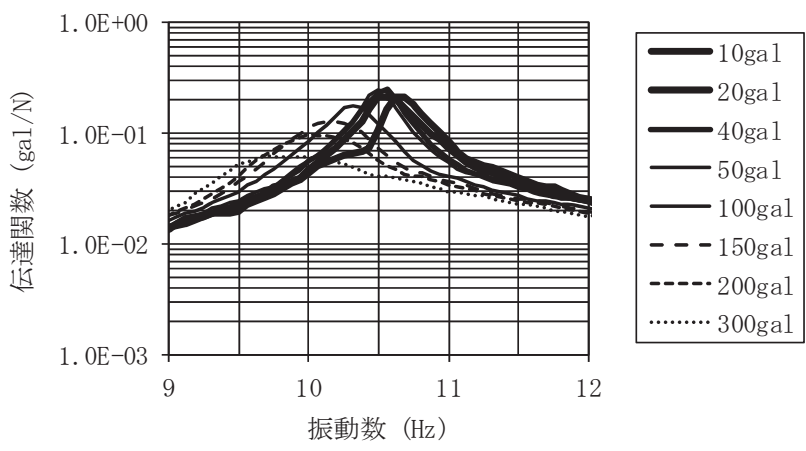

図 13 加振器による加振時における加振力から梁中央部の 加速度センサ信号までの伝達関数

\section{5. 縮小梁模型の振動制御実験}

膜型圧電セラミックスを用いて縮小梁模型の鉛直振動を制御する 実験を行った。図 16 に示寸ように, 梁模型の両端部に配置した膜 型圧電セラミックスのうち一方の膜型圧電セラミックスをセンサと して用い, この検出信号を基に他方のアクチュエータ用膜型圧電セ ラミックスより制御力を発生させる. なお, 前章の結果より, 積層

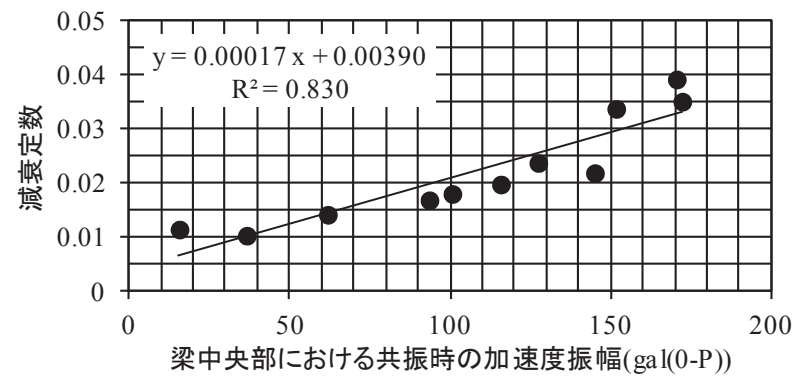

図 14 共振時の最大加速度振幅と減衰定数の関係

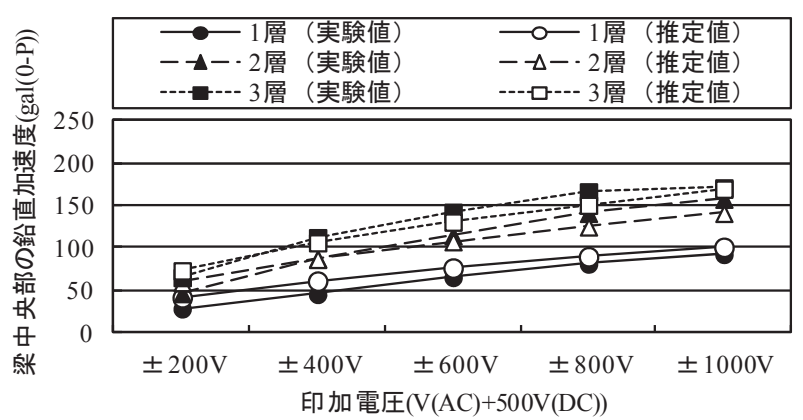

図 15 膜型圧電セラミックス駆動時の梁中央部における最大加速度 (推定値補正後)

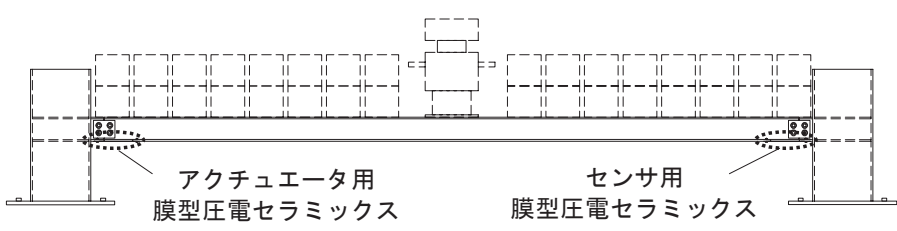

図 16 アクチュエータ用膜型圧電セラミックスとセンサ用 膜型圧電セラミックスの配置

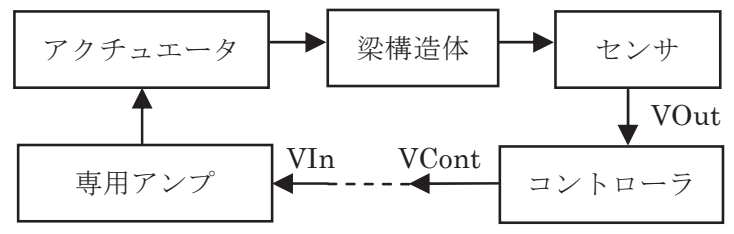

図 17 制御系のブロックダイアグラム

枚数が 1 層の場合でも梁中央部にて最大約 $80 \mathrm{gal}(0-\mathrm{P})$ の加振ができ ていることから微振動領域に対しては充分な制御力を有していると 考えられるが，両端部の膜型圧電セラミックスのうち片側のみをア クチュエータとして用いること等の理由から, 以降の検討はより制 御力に余裕のある積層枚数 2 層で行うこととした.

図 17 に制御系のブロックダイアグラムを示す。初めに，アクチ ユエータ用膜型圧電セラミックスを駆動させ，センサ用膜型圧電セ ラミックスから出力される電圧信号を検出する実験を行った. 図 18 に，専用アンプヘ入力した $3 \sim 200 \mathrm{~Hz}$ のスイープ電圧信号（VIn）か らセンサ用の膜型圧電セラミックスより出力された電圧信号 （VOut）までの伝達関数を示す. 図より, 梁模型の一次固有振動数 の $10.6 \mathrm{~Hz}$ が明確に検出されており, 振動制御のためのセンサ信号と して用いることができることを示唆している. 得られた伝達関数を 用いてフィードバック型の制御系を作成した。 図 19 に, 作成した 制御系の開ループ伝達関数 (専用アンプヘの入力電圧 VIn から制御 信号 VCont までの伝達関数）を示す．なお，本実験では梁模型の一 次固有振動数 $10.6 \mathrm{~Hz}$ のみを制御対象とした. 
以上に述べた制御系を用いて，外乱振動に対する振動制御実験を 行った. 外乱振動の発生は梁模型の中央部に設置した起振器により 行い, 梁模型の一次固有振動数である $10.6 \mathrm{~Hz}$ での正弦波加振と 3 $\sim 100 \mathrm{~Hz}$ のスイープ加振を行った. 図 20 に，正弦波加振時におけ る制御前後の梁模型中央部の鉛直加速度波形を示す. 図より, 制御 状態とすることにより加速度振幅が急速に低減され, 非制御状態の 加速度振幅に対して $1 / 3$ 以下に制御されていることが分かる. 図 21 に，スイープ加振時の梁中央部における加速度スペクトルを示す.

非制御状態と比較して制御状態では, 他の周波数を大きく増幅さ せることなく $10.6 \mathrm{~Hz}$ における加速度振幅のピークを約 $1 / 4$ 程度に 低減できていることが確認できる. 以上の実験により, 提案した膜 型圧電セラミックスを用いた制振手法により，梁架構の鉛直微振動 が制御可能であることを確認した。

\section{6. おわりに}

本報では, 重量構造物である梁架構の鉛直微振動を対象として, 膜 型圧電セラミックスを用いた制御手法を提案した。続いて, 膜型圧 電セラミックスの基本特性を示すとともに, 縮小梁模型を用いた実 験を通して提案した制御手法の実現可能性を見出した。また, 膜型 圧電セラミックスを複層化させることにより制御力を増強させる検 討や, FEM 解析により膜型圧電セラミックスおよび梁架構の挙動 を推定する手法の検討を行い,これらの有効性を見出した.今後は, 実大梁架構の制御へ向けた更なる制御力増強手法の検討や，ラーメ ン架構の水平振動制御，1 つの膜型圧電セラミックスをセンサ兼ア クチュエータとして用いた, より高度な制御手法の検討等を行う予 定である.

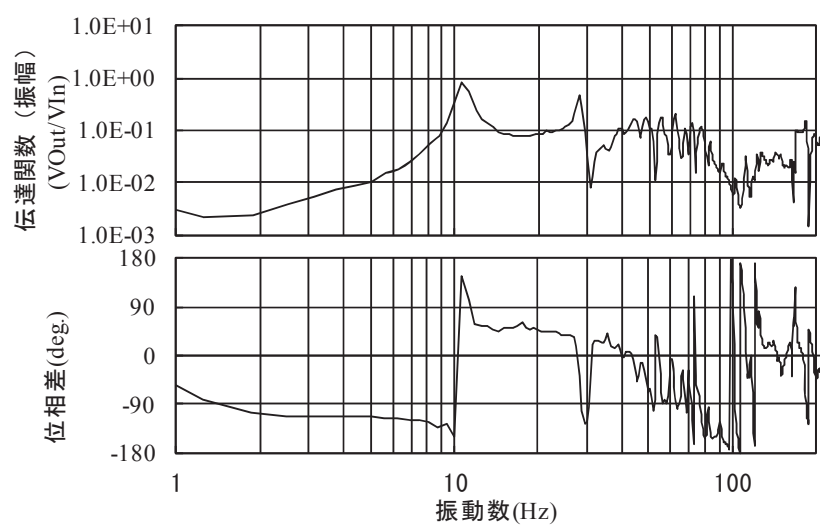

図 18 専用アンプへの入力信号からセンサ用膜型圧電 セラミックスの出力信号までの伝達関数
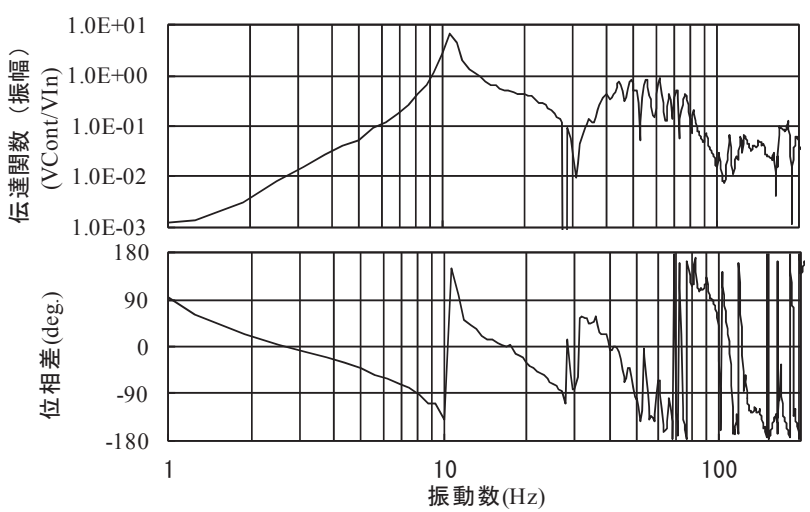

図 19 制御系の開ループ伝達関数

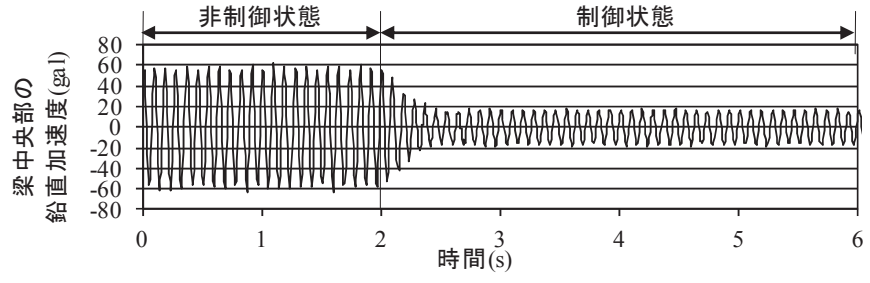

図 20 正弦振動 (10.6Hz) に対する振動制御結果

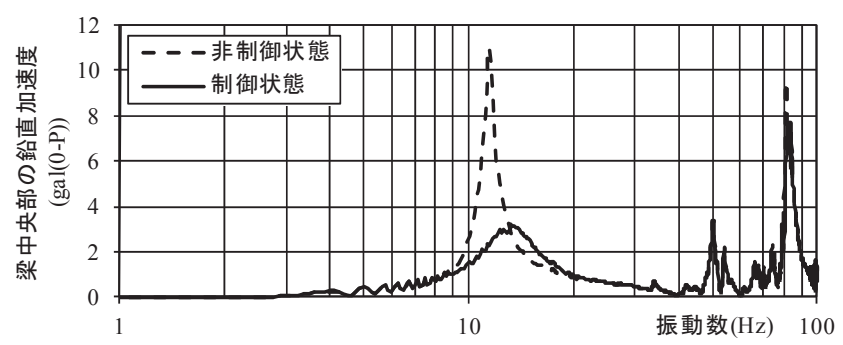

図 21 スイープ振動 $(3 \sim 100 \mathrm{~Hz})$ に対する振動制御結果

\section{参考文献}

1) 荻野伸行ほか 4 名：アクティブ制振装置の交通振動対策への適用，日本建 築学会大会学術講演梗概集，構造 II ，pp. 457-458，2001.9

2) 田中靖彦ほか 1 名: 床振動と固体伝搬音のアクティブ制御に関する研究, 日本建築学会環境系論文集，第 587 号，pp. 1-8，2005.1

3) 西垣勉ほか 2 名 : 圧電フィルムによるはり振動の検出と制御, 日本機械学 会論文集（C 編），Vol.63，No.615，pp. 32-38，1997.11

4) Eric Ruggiero et al. : Multi-input Multi-output Modal Testing Techniques for A Gossamer Structure, Proceedings of IMECE 2002, pp. 167-175, 2002.11

5) Hartmut Janocha : Adaptronics and smart structure Basics, Materials, Design, and Applications, Springer-Verlag Berlin Heidelberg, 1999

6）嶋崎ほか 6 名: 大形ピエゾアクチュエータを用いたスマート構造による建 築構造物のアクティブ制振, 日本機械学会論文集（C 編），Vol.67, No.656, pp. 985-991，2001. 4

7) M. Shimazaki, et al. : "Active Microvibration Control in Base-isolated Precision Manufacturing Facilities with Smart Structure using Piezoelectric Actuators," 13th World Conference on Earthquake Engineering, Vancouver, B. C., Canada, August 1-6, 2004.

8) H. Hora, et al., Feasibility Study of Active Micro-vibration Control System using Piezoelectric Actuators for Floor Structure of Precision Manufacturing Facilities, The 14th World Conference on Earthquake Engineering, Bei jing, China, 2008.

9) 竹下昌樹ほか 3 名 : 圧電ダンパーの基本的特性と建築構造物への適用に関 寸る基礎的研究, 日本建築学会構造系論文集, 第 564 号, pp. 47-54, 2003.2

10) 安達ほか 2 名: 圧電素子を用いた構造物の受動/能動混成型制振システム の設計に関する研究，日本機械学会論文集（C 編），Vol.66， No. 652， pp. 3867-3873, 2000. 12

11) 竹下昌樹ほか 4 名: 建築構造物のスマート構造化に関する基礎的研究，(そ の 4) 圧電素子を用いた能動的制御の可能性（実験結果とその考察），日 本建築学会大会学術講演梗概集, 構造 II , pp. 839-840, 1999.9

12) 熊谷知彦ほか 4 名: 圧電フィルムを用いたアーチ構造物のアクティブ制振 実験一その 1-, 一その $2-$, 日本建築学会大会学術講演梗概集, 構造 I, pp. $675-678,2011.8$

13) 高橋ほか 2 名: MFC を利用した建築構造体の振動制御に関する研究, 第 55 回自動制御連合講演会, pp. 1737-1738，2012.11

14)W. Keats Wilkie et al. : Low-Cost Piezocomposite Actuator for Structural Control Applications, Proceedings of SPIE, Vol. 3991, pp. $323-334,2000$

(2012年 5 月 8 日原稿受理, 2012 年11月15日採用決定) 